\title{
Chagasteger
}

\author{
Mellom 16 og 18 millioner mennesker i Latin-Amerika og USA lider \\ av Chagas' sykdom. Vektorene som overfører sykdommen har ikke \\ hatt noe norsk navn.
}

Chagas' sykdom overføres i forbindelse med at visse tegearter suger blod av mennesker om natten. Smitteagens, Trypanosoma cruzi, overføres ikke ved selve bittet, men skilles ut $\mathrm{i}$ tegenes avføring og kommer inn i verten gjennom slimhinner eller ekskoriasjoner (1). Det finnes ca. 40000 arter av teger. Tegene som overfører Chagas' sykdom hører til familien rovteger, underfamilie Triatominae - på norsk triatominer (med betoning på den siste i-en som i flertall av en mine: miner) (ramme 1).

Ca. halvparten av de 115 kjente artene av triatominer kan overføre sykdommen, men det er fem arter som er viktige: Rhodnius prolixus (fig 1), Triatoma infestans, $\mathrm{T}$ brasiliensis, $\mathrm{T}$ dimidiata og Panstrongylus megistus. Disse fem artene blir lett infisert av T cruzi og de har nær kontakt med mennesker, fordi de oppholder seg i sprekker i husveggene. Dessuten defekerer de straks etter at de har sugd blod, mens de fortsatt er på verten (2).

I engelskspråklig litteratur kalles triatominer som kan overføre Chagas' sykdom «kissing bugs», eller «Chagas bugs». I norske medier har ordet «kyssebiller» vært brukt, men dette er teger og ikke biller, og «kysse» er en svært dårlig metafor i denne sammenhengen. Ordet «chagasteger» har til nå ikke vært å finne i noen ordliste på norsk, men denne beteg-

\section{Ramme 1}

Klasse: Insecta, insekter

Orden: Hemiptera, nebbmunner

Underorden: Heteroptera, teger

- Famile: Reduviidae, rovteger

- Underfamilie: Triatominae, triatominer

nelsen har vært brukt blant norske infeksjonsmedisinere, og er nylig kommet inn i nettutgaven av Store norske leksikon (3).

\section{Gunnar Hasle}

hasle@reiseklinikken.com

Reiseklinikken

St. Olavs plass 3

0165 Oslo

\section{Litteratur}

1. Kirchhoff LV. Trypanosoma species (American trypanosomiasis, Chagas' disease): biology of trypanosomes. I: Mandell GL, Bennett JE, Dolin $R$, red. Principles and practice of infectious diseases. Philadelphia: Churchill Livingstone, 2000: 2845.

2. Peters W. A colour atlas of arthropods in medicine. London: Wolfe Publishing, 1992.

3. Store norske leksikon. www.snl.no/chagasteger (26.1.2010).

Manuskriptet ble mottatt 2.11. 2009 og godkjent 21.12. 2009. Medisinsk redaktør Raida Ødegaard.

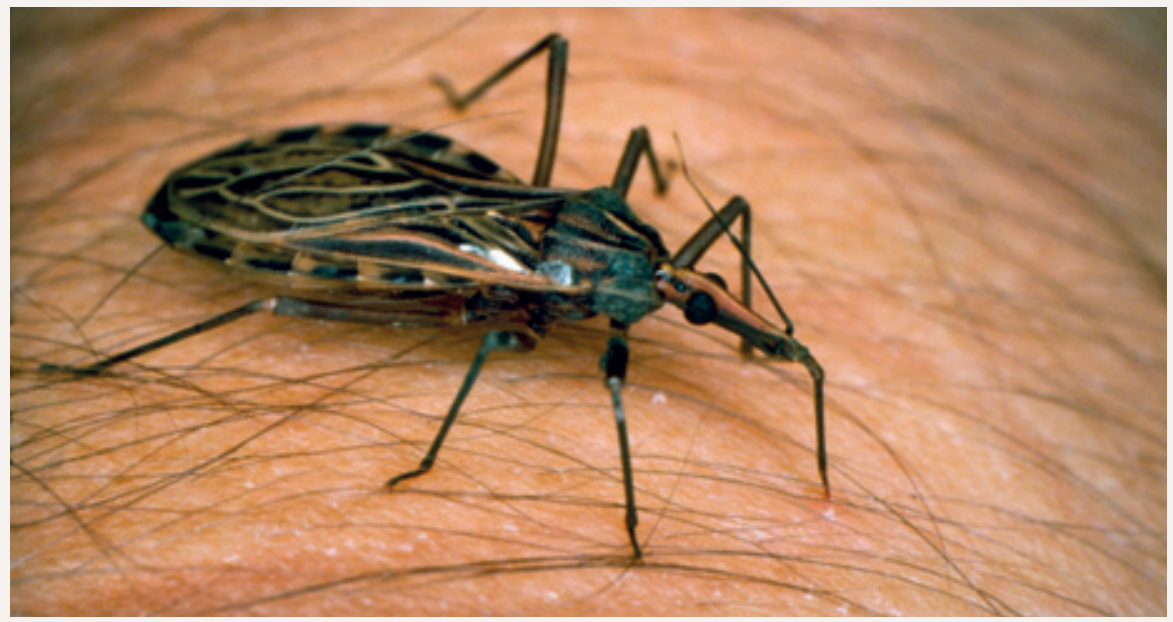

Chagastege, Rhodnius prolixus. Foto Martin Dohrn. Illustrasjonsfoto Science Photo Library/ GV-Press/NordicPhotos 